\title{
The Uses of Gold and its Technology as Recorded in Early British Patents
}

\author{
Anselm Kuhn \\ Finishing Publications Ltd, PO Box 70, 105 Whitney Drive, Stevenage, Hertfordshire, SG1 4DF, UK; E-mail. \\ FinPubs@compuserve.com
}

Received: 26 February 1999

\begin{abstract}
A brief history of the origin of patenting is given. A 1421 Florentine patent to Brunelleschi is believed to be the earliest invention granted such protection. Various rulers then granted patents for operation in their territories. The first organized approach to patenting was set up in London in the seventeenth century, and this was later systematized by Bennet Woodcroft. Some examples are given of early patents claiming applications for gold technology in areas such as cladding, electroplating and weaving gold wire.
\end{abstract}

\section{THE BRITISH PATENT SYSTEM AND BENNET WOODCROFT}

The granting of 'Letters Patent' by the King or other ruler of a country or state goes back at least to 1421, when the Florentine engineer, Brunelleschi was acknowledged as the inventor of hoisting gear and his rights as an inventor protected within that City-State. Such 'Letters Patent' granted exclusive rights to an inventor or just as commonly, to some favoured nobleman who was granted a trading monopoly on some specific commodity. Broadly speaking, these were favours bestowed by the ruler on a favoured subject - and they could be withdrawn as speedily as they were granted in the first place. It was in Great Britain in 1617, however, that the world's first systematic patent system was set up, and it has operated continuously ever since, though not without a few hiccups on the way. In the mid-nineteenth century, the system came close to collapse. Patents could be filed in several Crown offices and partly as a result of this, it became ever more difficult to establish what had previously been claimed or invented, so jeopardising the entire concept of 'Prior Art'.

To the rescue, came a most remarkable man, Bennet Woodcroft who - initially at his own expense - reorganized the system, most crucially setting down in print a "Name Index' where patents, their titles, dates, numbers and inventors were, for the first time systematically collated. Building on this, he then produced for each patent, an 'abridgement' (abstract) and classified each document into one of about 100 Classes. Parliament duly recognized the value of Woodcroft's achievements by buying from him the Index he had set up, and then by appointing him as 'Superintendant of Specifications' in 1852, at the then formidable salary of $£ 1000$ per annum. This story is admirably told in the book 'The Indefatigable $\mathrm{Mr}$ Woodcroft' (1). His Name Index was published around the same time, and then republished over 100 years later in facsimile form (2) with a useful historical introduction. Of Woodcroft's many other achievements, there is space here only to mention his responsibility for the founding of the world-famous Science Museum in South Kensington, London, and also the Patent Office Library which in turn became the National Science Reference Library and, as this is being written, is moving into the new British Library building in St Pancras, London. A brief word is in order as to the patents themselves. For the first century or more after 1617, patents were hand-written on vellum or parchment, some heavily adorned with seals. As part of his rationalization exercise, Woodcroft had all of these reprinted. It is these reprints, dating from around 1852 , which are open to public inspection. The original documents are now - to the extent they have survived at all - carefully preserved in museums or similar institutions, or in some cases held by private collectors.

\section{PATENTS AS A KEY TO TECHNOLOGY}

If we move back in time to the 17 th century, how were technologies and technological advances recorded? There 
were of course printed books by this time but in the main, these were reserved for the wealthier folk. Comparatively few books dealt with technological matters. The Royal Society wasted no time after its inauguration in the 17 th $\mathrm{C}$, in publishing its own journals such as Philosophical Transactions. However, when the first British Patent was filed in 1617, this august body had not even been conceived. But perhaps more to the point, it was mainly science and not technology, which preoccupied the Royal Society and similar bodies elsewhere in Europe. Practical applications of technology rarely found their way into the publications of these Learned Societies and indeed - as we will see below - such knowledge was actively suppressed.

In the 17 th century, and virtually without exception, all branches of technology fell under the domination of one or other of the Craft Guilds. Watch and clockmaking, gold and silversmithing, glassware all were totally controlled by the Craft Guilds. These guilds guarded their technology and its secrets most jealously. Apprentices served their time, worked their way up over many years to Master Craftsman. As part of this process, these craftsmen were (and the words remain in use to this day) 'Initiated into the Mysteries' and swore not to divulge their technological secrets. Thus it was that, far from disseminating technology, the Guilds made every effort to suppress such knowledge.

Though not asserting that these early Patents constitute the only source of information on the technologies of their time, there is no disputing their importance as the only systematic means by which advances can be mapped.

In 1997, with the Woodcroft book (2) long out of print, a project was set up to computerize Woodcroft's 'Name Index' and - thanks to the support and cooperation of the British Library, without which the exercise could never have been started, the first stage was recently completed, with the original 'Name Index' recreated as a CD-ROM (3), covering the period from 1617 to 1853 . In this form, however, and unlike the printed versions, the data held can be endlessly searched, ranked or classified in other ways.

\section{GOLD IN EARLY BRITISH PATENTS}

Using the search power of the CD-ROM version key words such as 'gold' and 'precious metals' can be used to search for specific data. The following account offers a partial overview of gold patents filed in the early years. Immediately, a clear sub-division becomes apparent as between those patents which relate to the uses and applications of gold on the one hand, and the substantial number relating to its mining and extraction. This article considers those in the first category. Readers with a special interest in the second category can consult the CD-ROM (3) and are welcome to seek assistance from the author.

\section{Patents Relating to Uses for Gold}

In broad terms, most of the hundred or so gold-related patents filed in the first 250 years can be classified as follows:

- use of gold thread in weaving and textiles

- cladding of sheet or wire $e t c$, with gold

- working of gold to make wire, foil, leaf etc

- miscellaneous uses

The period covered by Woodcroft's Name Index and the CD-ROM also covers the period when electroplating began. Thus, in 1842, (Patent No. 9528) William Henry Fox Talbot (of photographic fame) disclosed the gold or silver plating of a metal, using a 'galvanic battery' as a power source. The patent also discloses the use of 'electrocleaning', still widely used today, for removal of surface contamination by evolving hydrogen. Also disclosed in this patent is the formulation for a 'gold dip' based on a 'convenient solution of gold mixed with nitrate of lead or hydriodate of zinc...' In another formulation, he includes chloride of gold mixed with a solution of boracic acid. For brightening dark deposits of gold, Fox-Talbot proposed dipping into a dilute solution of mercury nitrate with alternating immersions in one of the gold solutions mentioned above, and the mercurial solution. Worth noting is the absence of any cyanides in his formulations and (mercury apart), FoxTalbot's solutions appear to be suitable for domestic use as a 'Gold Dip'.

In the previous year, Thomas Spencer (Patent No. 8865) had described the use of electroforming ('electrotyping') and electrogilding, "for the manufacture of picture and other frames and cornices...." The simple sketch (see Figure 1) illustrating his patent would be obvious to any teenaged scholar today.

Gold buttons were an essential feature of gentlemens' clothing and the means by which a goldfaced button was made are shown in Patent No. 959 dated 1770 . The simple punch and die arrangement, shown in Figure 2, would have been affordable by the button makers of the day. Thin gold sheet was stamped over a base metal substrate, with serrations formed by the die holding the gold covering onto the base.

The 'Gilding, Colouring and Marbling of Paper' is described in Patent No. 770 of 1762 . 'Take gold or 


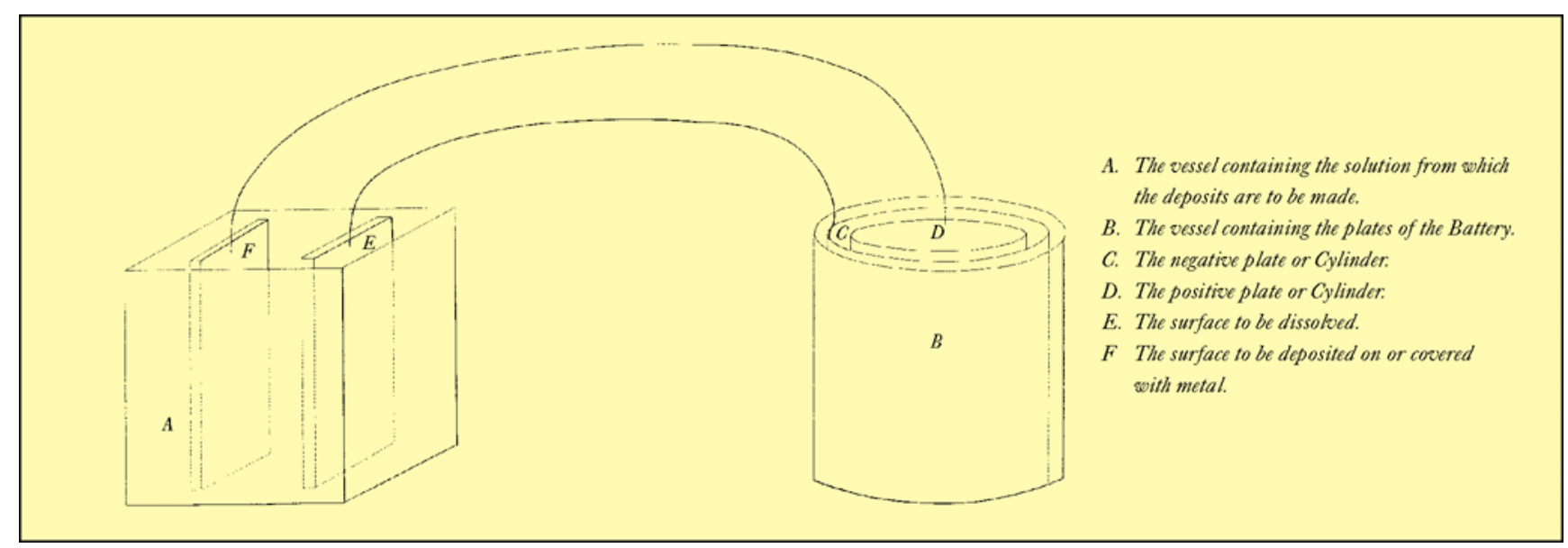

Figure 1 Schematic showing electrotyping or electrogilding circuit (British Patent 8865, dated 1841)

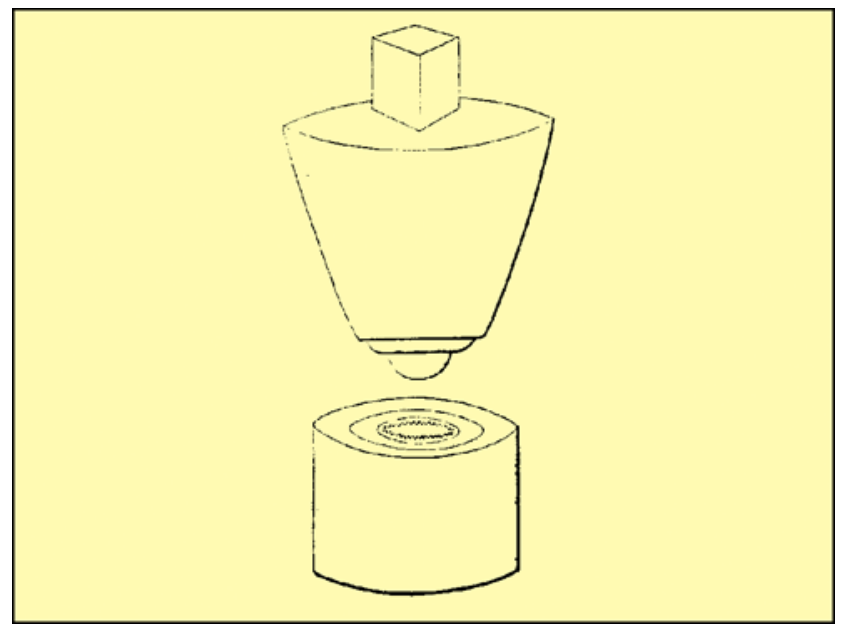

Figure 2 Punch and die for gold-cladding of buttons, etc (British Patent 959, dated 1770)

silver leaf, the colour to be taken from Brasil wood, rasped and boiled indigo, lecemus, statz meing, french beer, French grinspan, all made fine and thinned with water and spirits, the pattern to be engraved on copper, upon which the collours are to be laid and thereon lay the paper and press it with a skrew press". As with all these early patents, the document concludes with the words: "And be it remembered that on the said ninth day of July, in the year above written, the aforesaid Henry Houseman came before our said Lord the King, in his Chancery...." The profession of Patent Agent is comparatively recent.

In some of the early patents, little more than a concept is disclosed. However in others, there is minute and step-by-step detail, as for example in Patent No.1511 (1785) for the covering of buckles with gold, either with or without chasing them. The method involves a soldering, based on tin. Tin was also the means used by Whitworth, in his patent (No. 1755) dated 1790 , for plating metals with gold and other coatings. "Plating" at this time simply meant cladding, not electroplating. A drawing from Patent No. 1755 is reproduced in Figure 3.

In earlier times as is the case now, gold was too precious a metal to be treated cavalierly. Andrew's Hydrostatic Balance or Weighing Machine (Patent No.1053, dated 1773) could be used to detect counterfeit gold coins, a perennial problem, using Archimedes principle. "To discover the quantity of base metal in a piece of counterfeited gold coin, first weigh the piece in air, then put it in the noose which is in the above-mentioned piece of Indian grass, gold wire or silk and suspend it in water, whereupon the before-mentioned scale and characters upon the slides .... will shew and prove the quality of base metal."

Doubtless honestly intended for decoration and doubtless used by the dishonest to deceive, Dovey's "Method of Amalgamating Metals to Resemble Gold" and "Making a Metal of the Colour and in all Respects Resembling Gold" used copper, tin, zinc or spelter, antimony, red lead, manganese ore and crocus martus ore, which were melted and heat-treated so that the alloy was "Fit for manufactoring into diverse articles by flatting or remelting for buckles, sleeve buttons, watch cases, candlesticks etc".

Then as now, the demands of fashion drove technology and the weaving of cloth with gold thread was clearly of some importance with several patents describing the machinery to be used for this, such as Patent No.1606 (1787) or 1096 (1775) to Thomas Trentham. Figure 4 shows his loom and a strange handheld brush for use after the weaving was complete.

John Moore filed a further related patent in 1811 entitled "Machine for the manufacture of gold \& silver 


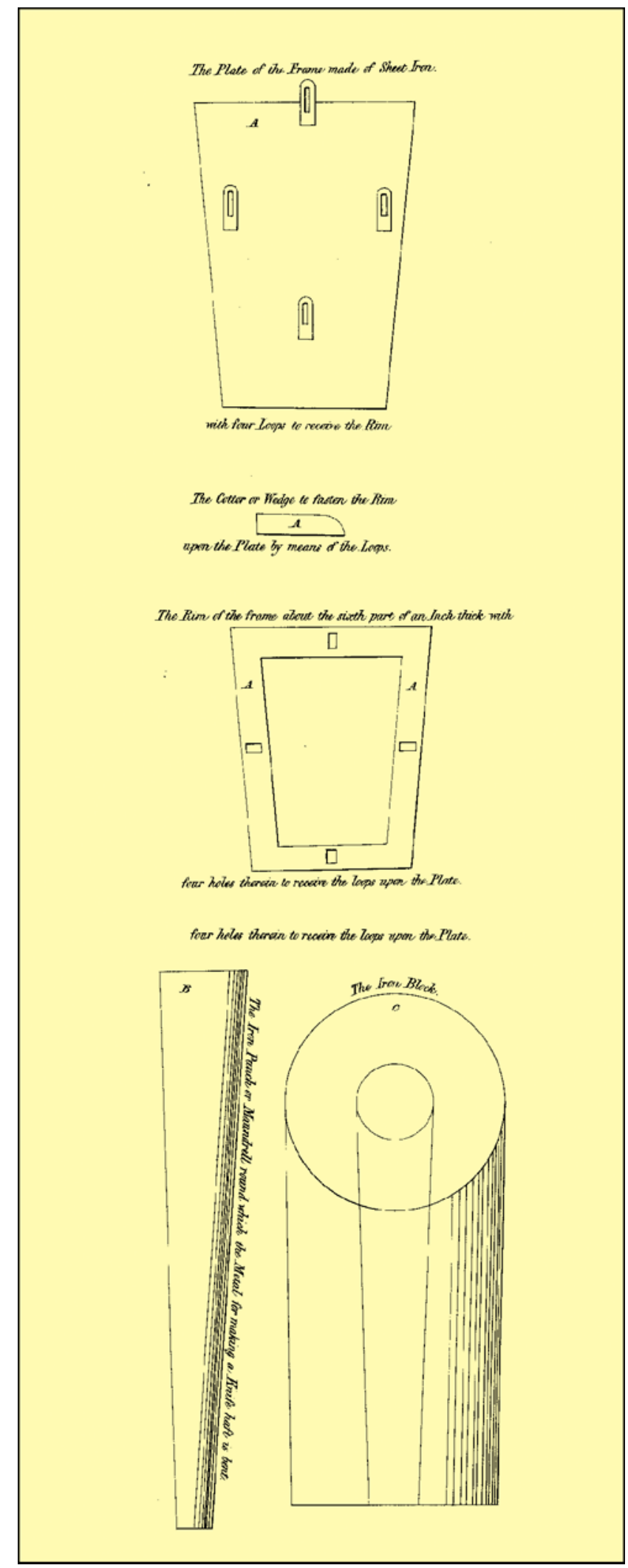

Figure 3 Arrangement for solder-cladding metal buckles etc, with gold (British Patent 1755, dated 1790) twist...." (Patent No. 3443). By this time, many of the drawings accompanying the patents were virtually engineering drawings, as can be seen from Figure 5 showing a fairly complex piece of textile machinery.

Fashion too, one presumes, underlay Mather and Farrand's "New Method of Gilding upon Linen, Cotton etc" (Patent No. 1633, dated 1787) in which gold leaf was "callendered" with the fabric or leather.

\section{WOODCROFT'S ABRIDGEMENTS}

Bennet Woodcroft not only published his famous 'Name Index' which simply listed the inventors, patent numbers and titles and the year of their granting but also produced a series of 'Abridgements' (we would call them 'abstracts' today). These were published in an initial series of some 100 volumes, classified according to their subject matter.

Most of the early patent abridgements relating to the use of gold are included in Volume 23 (4) ("The Plating of Metals upon Metals"). Before listing these patents, Woodcroft sets out a chronological history of 'plating'. He begins by noting that 'Holy Writ', while frequently referring to gilded wooden structures, provides no account of how this was done. He makes passing reference to the ancient Egyptians, as recounted by Herodotus, cites Pliny's account in $\mathrm{AD}$ 77 of 'fire-gilding' using quicksilver. He then moves on to mention Anketil, a monk from St Albans, famed in the 12th Century for his gilding work. In 1698, 'Dry gilding' was described. Linen rags were steeped in a solution of gold salts, then burnt and, with a cloth dipped in salt water, the ashes were rubbed over silver plate, so lightly gilding it. In 1805, Brugnatelli reported what was in effect gold electroplating and so onwards to more modern times.

\section{THE EARLIEST BRITISH PATENTS FOR PLATING OR CLADDING WITH GOLD}

George Whately, in 1768 was granted Patent No. 905, with two claims. The first claim was "Method of plating silver upon metal wire and drawing the same into wire of very fine sizes, both round, flat and square, and of drawing the same so fine as to make thread, lace, fringe and tinsel". The second claim was a "Method of plating gold upon silver wire..." and drawing this as in the first claim. 


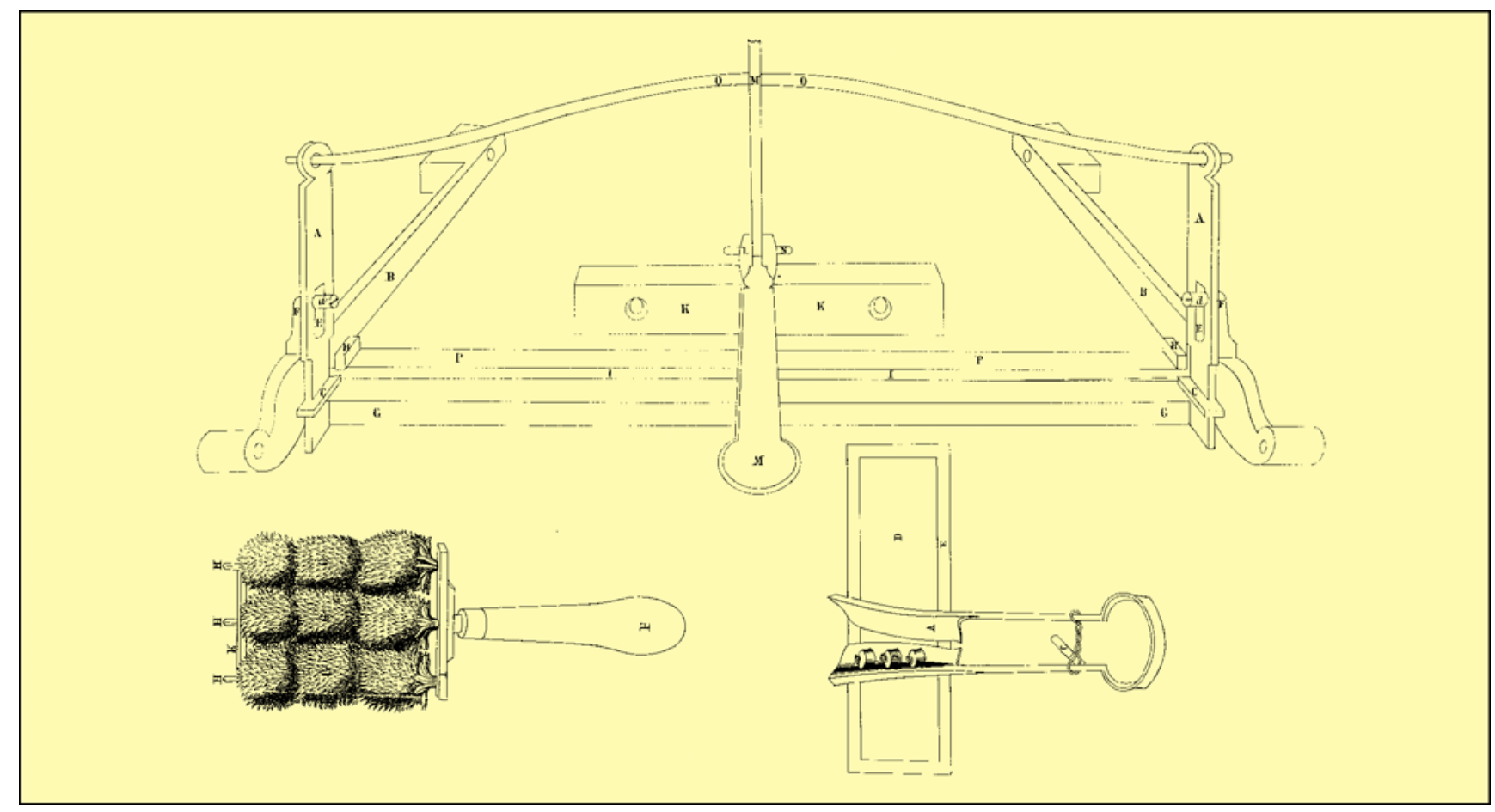

Figure 4 Loom for weaving cloth with gold thread (British Patent 1606, dated 1787)

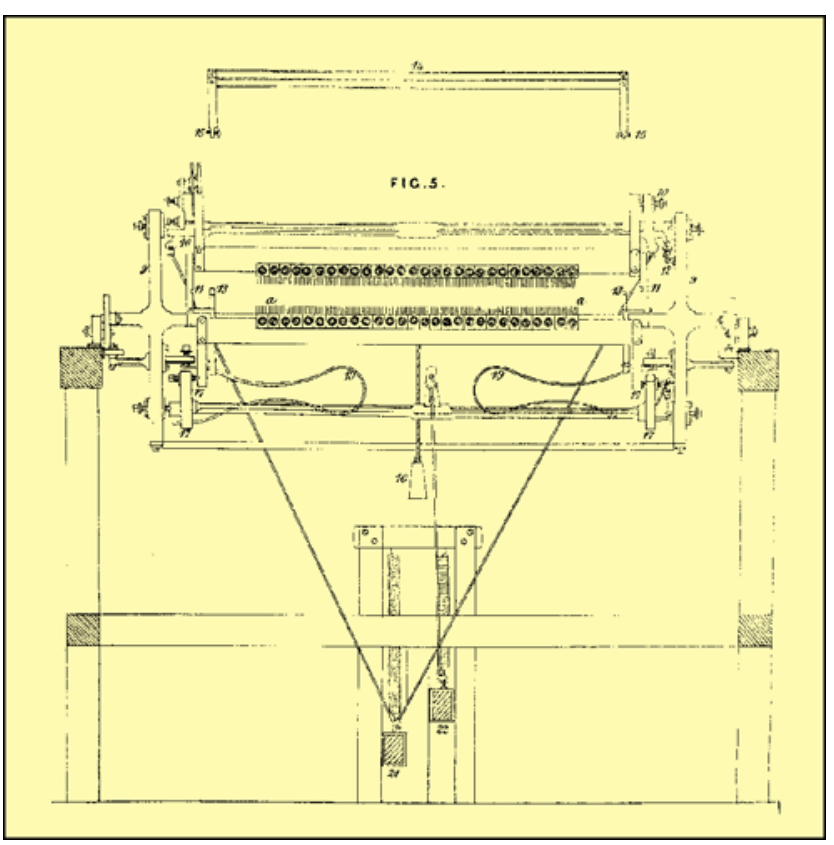

Figure 5 Machine for the manufacture of gold and silver twist (British Patent 3443, dated 1811)

The same inventor, in the same year, was granted Patent No. 908 "New-invented method of plating gold upon silver-plated metal wire and of drawing such wire, when plated with gold, into wire of very fine sizes both flat, round and square and of drawing the same so fine as to make thread, lace, fringe and tinsel and be useful in various branches of business and manufactories as real gold wire thread, lace, fringe and tinsel and a great saving and benefit to his Majesty's subjects". This broadly followed the earlier document and the purpose is clearly as old as the decorative use of gold itself, an effort to pass-off base metals as gold.

Ten years later, in 1778, William Collins was granted Patent No. 1187 "A method of preparing, gilding, polishing and burnishing a metal (or metals) plated with silver, for making buttons and other articles in the toy way, both for use and ornament, by laying on the gold when the metal or metals are in a state of much more considerable thickness than when they have before been used for the purposes aforesaid". The key aspect appears to be the use of paired rollers but with one moving more slowly than the other.

One year later, in 1779, Richard Ellis, in Patent No. 1209 claimed "A Newly-invented method or mode of plating steel or iron with gold or silver". The areas to be plated are rubbed with borax, the gold or silver laid close. There follows a soldering operation, so illustrating the very broad sense in which the word "plating" was used.

On to 1785, where, in Patent No. 1466, William Playfair was granted "Certain new methods of making shoe, knee, stock and other buckles, of silver 
or other metals and of covering the surfaces of copper or other metals with silver, gold or mixtures of silver and gold with other metals which operation is commonly called plating". The substrate metal is covered with a sheet of gold or its alloy, but using an interleaf of silver-copper alloy, mechanically joined and then furnace-heated.

In the same year, James Alston is the inventor of Patent No.1511 "Lining, edging, plating and covering either in whole or in part, with silver or gold, or otherwise, buckles and other articles made of iron, copper or other mixed metals, by the use and application of tin or alloyed tin". Twelve process stages are listed, beginning with tinning, then mechanical application of silver leaf, but with option of casting less noble metal blanks into molten silver. In Process No. 12 "Coat, breast or vest buttons of sheet iron" are covered with tin, silver, gold by burnishing and application of the outer metal using a hot rotating iron barrel.

Buttons are again the subject of Patent No. 1586, assigned to Robert Hickman in 1787. "A new method of making and manufacturing gilt and plated coat and waistcoat buttons, by uniting or amalgamating with or by means of tin or tin and lead mixed, gilt and plated metal button shells, both coloured, plain, and figured with bottoms of copper, brass, iron, mixed and compound metals". After tinning, the buttons are inlaid with gold by means of dies....

After some 30 years, John Turner, in Patent No. 4182 (1817) discloses “The improvements of plating copper or brass or copper and brass mixed with pure or standard gold, or with gold mixed with a greater portion of alloy, so that when plated it may be rolled into sheets". The method involves placing a sheet of gold adjacent to the ingot of (say) copper, then compressing the two by hammering or binding with wire. A mixture of silver filings and borax is then laid "upon and along the edge of the piece or plate of gold ..." so that fusion results. Alternatively, "other kinds of solder" may be used.

Abridgements, Volume 23, takes us on to the beginnings of electroplating (an example is cited above) and comes to a close with the great work of the Elkington family in Birmingham (see Editor's note below) who may not have actually discovered electroforming or 'electrotyping' but who used these methods in conjunction with gold and silver plating to produce original designs and also replicas of famous pieces of tableware and effectively converted what had hitherto been a craft, into a substantial industry.
Many other gold-related patents fell under other classifications, as for example the manufacture of gold leaf and gold thread, the "chasing of coffin furniture, ornaments for coaches, chariots, sedans, cabinet work and domestic furniture in gold, silver..." or the "drawing of tubes plated with silver or gold... for telescopes..."

To spend time delving into this treasure house of information is to be fascinated at how much was already known and understood so many centuries ago, it is to meet again names still famous today, whether Fox-Talbot, or Mather (of Mather \& Platt textile fame). For the craftsman or craftswoman, desiring to re-create the artefacts of the past, here in many cases are detailed recipes. The present account can do no more than "give the flavour".

Woodcroft's Name Index (2), in its printed form was re-issued in the 1960's but is again long out of print. For those who care to explore the 14,000 or so patents and their inventors, covering the timespan 1617 to 1853 , the re-issue of this as a CDROM (3) allows readers to search or just browse and thus to view the development of technology from the time of "Merrie England", right through the fires of the Industrial Revolution and on to the great days of Victorian industrial supremacy. Through this period of almost 250 years, the importance of gold in all aspects of a nation's life is evident. Just as it is today.....

\section{ACKNOWLEDGEMENTS}

The author wishes to thank Dr David Newton and his staff, especially Mr Steve van Dulken, at the British Library (Patents Division) for their support in this project; and Ms Pauline Dingley and her staff at the Science Museum Library, South Kensington, London. Also, Mrs Sandra Santos-Costa and Mrs Jan Townsend who produced the database.

\section{ABOUT THE AUTHOR}

Dr Anselm Kuhn has a long-standing interest in the History of Science and Technology. For the past two years his company has been engaged in a joint project with the British Library with the aim of making the literature on early British Patents available in computer-readable format. Publication of the CDROM 'A Cradle of Inventions' was the first fruit of this project, with further publications due to appear by the 
end of 1999. The longer term plan is to make the material available on the Worldwide Web.

\section{REFERENCES}

1 'The Indefatigable Mr Woodcroft', J. Hewish, Publ. British Library (History of Technology Series, No. 1), London, 1980

2 'Alphabetical Index of Patentees of Inventions. 1617-1852'. Bennet Woodcroft, first published. 1854, re-issued 1969, Evelyn Adams \& Mackay, London, pp. 647 (out of print). Complete collections of early British patents are held by the British Library, 96 Euston Road, London NW1 2DD and the Science Museum Library, South Kensington, London, where they can be viewed and/or photocopies can be supplied via mail.

3 'A Cradle of Inventions', CD-ROM, publ. MFIS Ltd, PO Box 70, Stevenage, Herts, SG1 4DF, UK

4 Patent Abridgements, 1617 to 1862, Vol. 23, 1864 'The Plating of Metals on Metals' (to be published shortly, in book and CD-ROM formats by MFIS Ltd, Stevenage, Herts, SG1 4DF, UK)

\section{EDITOR'S NOTE}

This paper highlights the value of patents in tracing historical developments on uses for gold. Readers may be interested in previous historical articles in Gold Bulletin. For example, that entitled 'Gold Embroidery and Fabrics in Europe: XI - XIV Centuries' by M. Jaro, Gold Bull., 1990, 23, 40 and references cited therein, traces the even earlier uses of gold thread and related matters. 'The Early History of Gold Plating' is the title of a relevant paper by our founder editor, L.B. Hunt, Gold Bull., 1973, 6, 16, in which the work of the Elkingtons is described. Early gilding descriptions are given in 'Mappae Clavicula, A Little Key to the World of Medieval Techniques', C.S. Smith and J.G. Hawthorne, The American Philosophical Society, Independence Square Philadelphia, 1974.

\section{DO YOU WANT TO ADVERTISE IN THIS JOURNAL

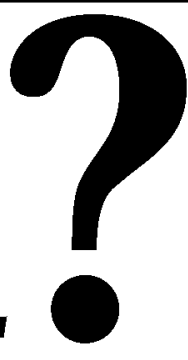

We are considering the introduction of a limited amount of advertising in Gold Bulletin. If you are interested in reaching an international audience of scientists and technologists in academia and industry with an interest in gold, this could be your opportunity.
Interested advertisers should contact the Editor, Dr C.W. Corti, World Gold Council, Kings House, 10 Haymarket, London SW1Y 4BP, England. Tel:+44 2079305171 - Fax: +442078396561 E-mail: chris.corti@wgclon.gold.org

\section{Call for Papers}

We are keen to publish primary experimental results on research investigations on gold and its derivatives. Short notes, papers and announcements of innovative

results will be equally welcome, especially where the gold materials used are key components.

Our interest in publishing review articles, book reviews, and conference proceedings will also continue. 